\title{
Genetic Polymorphism in Three Glutathione $S$-transferase Genes and Breast Cancer Risk
}

S. Woldegiorgis, R. C. Ahmed, Y. Zhen, C. A. Erdmann, M. L. Russell, R. GothGoldstein

Environmental Energy Technologies Division, Lawrence Berkeley National Laboratory

April 2002

Correspondence may be addressed to R. Goth-Goldstein, Mailstop 70-108B, Lawrence Berkeley National laboratory, One Cyclotron Road, Berkeley, CA 94720

This research was supported in part by funds from the California Breast Cancer Research Program of the University of California, Grant Number 1RB-0429. S. W., R.C. A., and Y. Z. were supported by the Center for Science and Engineering Education, Lawrence Berkeley National Laboratory. The work was performed under U.S. Department of Energy Contract No. DE-AC03-76SF00098. 


\begin{abstract}
The role of the glutathione $S$-transferase (GST) enzyme family is to detoxify environmental toxins and carcinogens and to protect organisms from their adverse effects, including cancer. The genes GSTM1, GSTP1, and GSTT1 code for three GSTs involved in the detoxification of carcinogens, such as polycyclic aromatic hydrocarbons (PAHs) and benzene. In humans, GSTM1 is deleted in about $50 \%$ of the population, GSTT1 is absent in about 20\%, whereas the GSTP1 gene has a single base polymorphism resulting in an enzyme with reduced activity. Epidemiological studies indicate that GST polymorphisms increase the level of carcinogen-induced DNA damage and several studies have found a correlation of polymorphisms in one of the GST genes and an increased risk for certain cancers.

We examined the role of polymorphisms in genes coding for these three GST enzymes in breast cancer. A breast tissue collection consisting of specimens of breast cancer patients and non-cancer controls was analyzed by polymerase chain reaction (PCR) for the presence or absence of the GSTM1 and GSTT1 genes and for GSTP1 single base polymorphism by PCR/RFLP. We found that GSTM1 and GSTT1 deletions occurred more frequently in cases than in controls, and GSTP1 polymorphism was more frequent in controls.

The effective detoxifier (putative low-risk) genotype (defined as presence of both GSTM1 and GSTT1 genes and GSTP1 wild type) was less frequent in cases than controls (16\% vs. $23 \%$, respectively). The poor detoxifier (putative high-risk) genotype was more frequent in cases than controls. However, the sample size of this study was too small to provide conclusive results.
\end{abstract}




\section{INTRODUCTION}

The majority of chemical carcinogens like polycyclic aromatic hydrocarbons (PAHs) require metabolic activation before they can interact with cellular macromolecules and initiate cancer. The pathway by which ingested or inhaled environmental toxins are metabolized is the stepwise oxidative activation by phase I cytochrome P450 isozymes and detoxification through conjugation by phase II enzymes like glutathione $S$ transferases (GST). Conjugation of the reactive chemical species to glutathione renders xenobiotics water-soluble and facilitates their elimination from the body. Therefore, this reaction plays an important role in the inactivation of toxic and carcinogenic compounds. The phase II GST isozymes are encoded by at least four distantly related gene subfamilies, GSTA, GSTM, GSTP, and GSTT (Hayes and Pulford, 1995: nomenclature as suggested by Mannervik et al., 1992). Each family may comprise several genes; for the $\mathrm{M}$ family at least five genes have been described, whereas only one gene is known for the $P$ family and two for the T family.

The various GST isozymes have different, but often overlapping substrate specificities, and different patterns of expression in different cells and tissues (Awasthi et al., 1993). GSTA and GSTM are highly expressed in liver. Most extrahepatic tissues express GSTP1. The GSTP1 gene is involved in the development of acquired resistance towards anticancer drugs (Hayes and Pulford, 1995). GSTT1 is expressed in human erythrocytes and in liver. GSTM1, which is also expressed in human lymphocytes, shows a high efficiency for conjugating epoxides and is particularly important for detoxification of PAH epoxides, the ultimate carcinogens of PAHs, but GSTP1 is also active towards PAH epoxides (Hayes and Pulford, 1995), and might compensate for loss of GSTM1 activity. GSTT1 catalyzes the conjugation of various smaller compounds, such as the industrial chemicals methyl chloride, methyl bromide, dichloromethane, ethylene oxide, and diepoxybutane, a reactive metabolite of 1,3-butadiene, in human liver and erythrocytes (Meyer et al., 1991). This enzyme may have both detoxification and toxification activities depending on the substrate, it detoxifies the carcinogen ethylene oxide, but may enhance the formation of the genotoxic formaldehyde from dichloromethane.

GSTs are part of a complex integrated detoxification system with an intricate regulation of gene expression of phase I and phase II enzymes partially through the Ah receptor (Hayes and Pulford, 1995). Most GST-inducing compounds effect transcriptional activation through a response element (primarily the antioxidantresponsive element and the xenobiotic-responsive element). There seems to be an interdependance between regulation of various GST genes as well as expression of other detoxification systems. For example, a lack of the GSTM1 gene results in decreased expression of another GST isozyme, GSTM3 (Nakajima et al., 1995) and reduces overall detoxification capabilities of affected individuals. In addition, the GSTM1 null genotype seems to increase the inducibility of the cytochrome P4501A1 (CYP1A1) gene (Vaury et al., 1995).

Interindividual differences in carcinogen metabolism, DNA repair, cell cycle control, programmed cell death, and other cellular functions all contribute to the carcinogenic process. Genetic polymorphisms are largely responsible for interindivdual traits; they can affect gene expression and protein function. The interindividual variations in carcinogen metabolism have been studied extensively and are recognized as an important 
determinant of susceptibility to various cancers (Nebert et al., 1996). In the metabolism of a procarcinogen, such as benzo[a]pyrene, a more efficient conversion of the procarcinogen to the ultimate carcinogen (the benzpyrene diol epoxide) by phase I enzymes can increase the risk of carcinogenesis, while a more rapid clearing by phase II enzymes can confer a protective effect. Variability in the level and activity of phase I and II enzymes is due, in part, to genetic polymorphisms. These can consist of single base substitutions or total gene deletions.

The GSTP1 gene has a single base change of an A to $\mathrm{G}$ that results in an amino acid change of Ile to Val, resulting in reduced enzyme activity (Harries et al., 1997, see Table 1). This variant has been associated with increased risk of cancer at various sites (Hirvonen, 1999). The GSTM1 gene is also polymorphic, containing two wellcharacterized, expressed genes and a null allele which reflects nearly complete deletion of the gene and results in total loss of GSTM1 activity (Seidegard et al., 1988). This GSTM1 gene deletion occurs quite frequently, in about $50 \%$ of the population, though there are large variations among different ethnic groups (Bell et al., 1992). Individuals with the null allele are at an increased risk for various cancers including cancer of the lung and bladder (Bell et al., 1993; McWilliams et al., 1995). Studies in Japanese populations that consider interaction of GSTM1 with smoking and/or CYP1A1 genotypes report a significant increase in lung cancer risk (Hayashi et al., 1992, Nakachi et al., 1992). GSTT1 also exhibits a deletion polymorphism (Nelson et al., 1995). Less is known about cancer susceptibility in individuals with GSTT1 deletion, but several studies have consistently shown evidence of increased DNA damage in individuals with the null allele (Rebbeck, 1997). The combined GSTM1 and GSTT1 null genotypes have been associated with increased lung cancer risk (Kelsey et al., 1997). The relative cancer risk associated with deletion of the GSTM1 and/or GSTT1 gene is probably small, but because of the high frequency of these deletion genotypes, there is the potential for broad population level impact. It has been estimated that the GSTMI null genotype accounts for $17 \%$ of lung cancer (McWilliams et al., 1995), as well as $17 \%$ of bladder cancer cases (Brockmoeller et al., 1994). This is in contrast to specific cancer genes such as p53 and BRCA1 which have a high individual cancer risk but low population frequency and a low population attributable risk, less than 10\% of all breast cancers (Caporaso and Goldstein, 1995).

Table1: GST genetic polymorphisms investigated in this study

\begin{tabular}{|c|c|c|c|}
\hline Gene & Base change & Functional effect & Detection method \\
\hline GSTM1 & Gene deletion & No enzyme & $\begin{array}{c}\text { Allelele-specific } \\
\text { PCR }\end{array}$ \\
\hline GSTP1 & $\begin{array}{c}\text { A to G transition } \\
\text { resulting in } \\
\text { Ile105Val change }\end{array}$ & $\begin{array}{c}\text { Reduced enzyme } \\
\text { activity }\end{array}$ & $\begin{array}{c}\text { PCR/RFLP as } \\
\text { Alw261 site created }\end{array}$ \\
\hline$G S T T 1$ & Gene deletion & No enzyme & $\begin{array}{c}\text { Allelele-specific } \\
\text { PCR }\end{array}$ \\
\hline
\end{tabular}


Because PAHs are known to cause mammary cancer in rodents, we hypothesize that they are involved in breast cancer development in humans. Variation in the metabolism of PAHs is likely to influence the risk of breast cancer. We have initiated studies analyzing a breast tissue collection of breast cancer cases and controls to evaluate how the efficiency of PAH detoxification, that is polymorphism in the GSTM1, GSTP1, and GSTT1 genes, affects breast cancer susceptibility.

\section{MATERIALS and METHODS}

Breast tissue collection: A collection of breast tissue from breast cancer patients and cancer-free individuals established by Dr. Martha Stampfer, LBNL, was used. The tissue bank contains specimens from reduction mammoplasties and mastectomies including tumor, peripheral non-tumor tissue, and in a few cases contralateral tissue. The age and disease status of the specimen donors are known. Individuals undergoing reduction mammoplasty - the control group - ranged in age from 15 to 68 years, mastectomy patients' age ranged from 30 to 87 years. For polymorphism analysis of the case group either tumor or peripheral non-tumor tissue was used

Prevention of PCR contamination: We have taken several precautions to prevent contamination of reactions with PCR product to avoid false positive results. The steps involved in the PCR procedure are (1) sample preparation, (2) PCR reaction set-up, (3) amplification, product analysis and quantitation. Each step is performed at a different workstation located in adjacent rooms where the work area for step 2 cannot be accessed from the work area for step 3. Each workstation has dedicated supplies and equipment, which cannot be brought into another area. The PCR set-up area is in a dead-air box equipped with UV light. All PCR reactions include a negative control.

Table 2: Oligonucleotide primer sequences for genetic polymorphism detection

\begin{tabular}{cccc}
\hline Gene & Oligonucleotides & Sequence & $\begin{array}{l}\text { PCR product } \\
\text { size (bp) }\end{array}$ \\
\multirow{2}{*}{ GSTM1 } & $\begin{array}{l}\text { Upper primer } \\
\text { Lower primer }\end{array}$ & $\begin{array}{l}\text { 5'-CTGCCCTACTTGATTGATGGG-3' } \\
\text { 5'-CTGGATTGTAGCAGATCATGC-3' }\end{array}$ & 273 \\
\multirow{2}{*}{ GSTT1 } & Upper primer & 5'-TTCCTTACTGGTCCTCACATCTC-3' & \multirow{2}{*}{480} \\
& Lower primer & 5'-TCACCGGATCATGGCCAGCA-3' & \\
\multirow{2}{*}{ GSTP1 } & Upper primer & 5'-ACCCCAGGGCTCTATGGGAA-3' & \multirow{2}{*}{176} \\
& Lower primer & 5'-TGAGGGCACAAGAAGCCCCT-3' & \\
\multirow{2}{*}{ 3-actin } & Upper primer & 5'-GGGCACGAAGGCTCATCATTC-3' & \multirow{2}{*}{320} \\
& Lower primer & 5'-TTTTTGGCTTGACTCAGGATT-3' & \\
\hline
\end{tabular}

Determination of GSTM1 and GSTT1 genotypes: The GSTM1 and GSTT1 genetic polymorphisms are determined simultaneously by multiplex PCR. For GSTM1, primers 
that hybridize to the $5^{\prime}$ region of exon 4 and 3' region of exon 5 of GSTM1 are used (Brockmöller et al., 1994; see Table 2). For GSTT1, the primers described by ToFigueras et al. (1997) are used. A $\beta$-actin fragment is amplified in parallel as a control for amplifiable DNA. PCR-reaction products are analyzed by gel electrophoresis (3\% agarose) and ethidium bromide staining for the presence of a $273 \mathrm{bp}$ GSTM1 product, a $480 \mathrm{bp}$ GSTT1 product, and a $320 \mathrm{bp} \beta$-actin product. The lack of a GSTM1 or GSTT1 amplification product in the presence of an actin amplification product is consistent with the homozygous null genotype. In all reactions, a positive and a negative control are included. As a quality control, 10-20\% of all samples are repeated as blinded duplicates.

Determination of GSTP1 genotype: The A to G polymorphism at codon 105 is determined by PCR of a $176 \mathrm{bp}$ fragment and restriction fragment length polymorphism (RFLP): the product is digested with the diagnostic restriction enzyme Alw261, which does not cut the consensus sequence, but cleaves the GSTP1 G allele to yield two restriction fragments of $91 \mathrm{bp}$ and $85 \mathrm{bp}$ length that can be analyzed by gel electrophoresis (Harries et al., 1997).

\section{RESULTS}

We determined GSTM1, GSTP1, and GSTT1 polymorphisms in 101 breast tissue specimens from the tissue bank established by M. Stampfer (62 cases and 39 controls). The GSTM1 and GSTT1 status was determined by a multiplex PCR assay that detects the

Table 3: GSTM1, GSTP1, GSTT1 genotypes detected in cases and controls

\begin{tabular}{|c|c|c|c|c|c|c|}
\hline \multirow[t]{2}{*}{ Gene } & \multirow[t]{2}{*}{ Allele } & \multicolumn{2}{|c|}{ Cases } & \multicolumn{2}{|c|}{ Controls } & \multirow[t]{2}{*}{ p-value ** } \\
\hline & & $\mathbf{n}$ & $(\%)$ & n & $(\%)$ & \\
\hline \multirow[t]{2}{*}{ GSTM1 } & $* 1$ & 28 & $(45)$ & 24 & $(62)$ & \\
\hline & $* 0$ & 34 & (55) & 15 & (39) & 0.11 \\
\hline \multirow[t]{3}{*}{ GSTP1 } & Ile/Ile & 30 & (48) & 17 & (44) & \\
\hline & Ile/Val & 29 & (47) & 18 & (46) & 0.57 \\
\hline & $\mathrm{Val} / \mathrm{Val}$ & 3 & (5) & 4 & (10) & \\
\hline \multirow[t]{2}{*}{ GSTT1 } & $* 1$ & 51 & (82) & 34 & (87) & \\
\hline & $* 0$ & 11 & (18) & 5 & (13) & 0.51 \\
\hline
\end{tabular}

\footnotetext{
$* 1$, nondeleted genotype, $* 0$, homozygous deletion

**Pearson Chi-Square test
} 


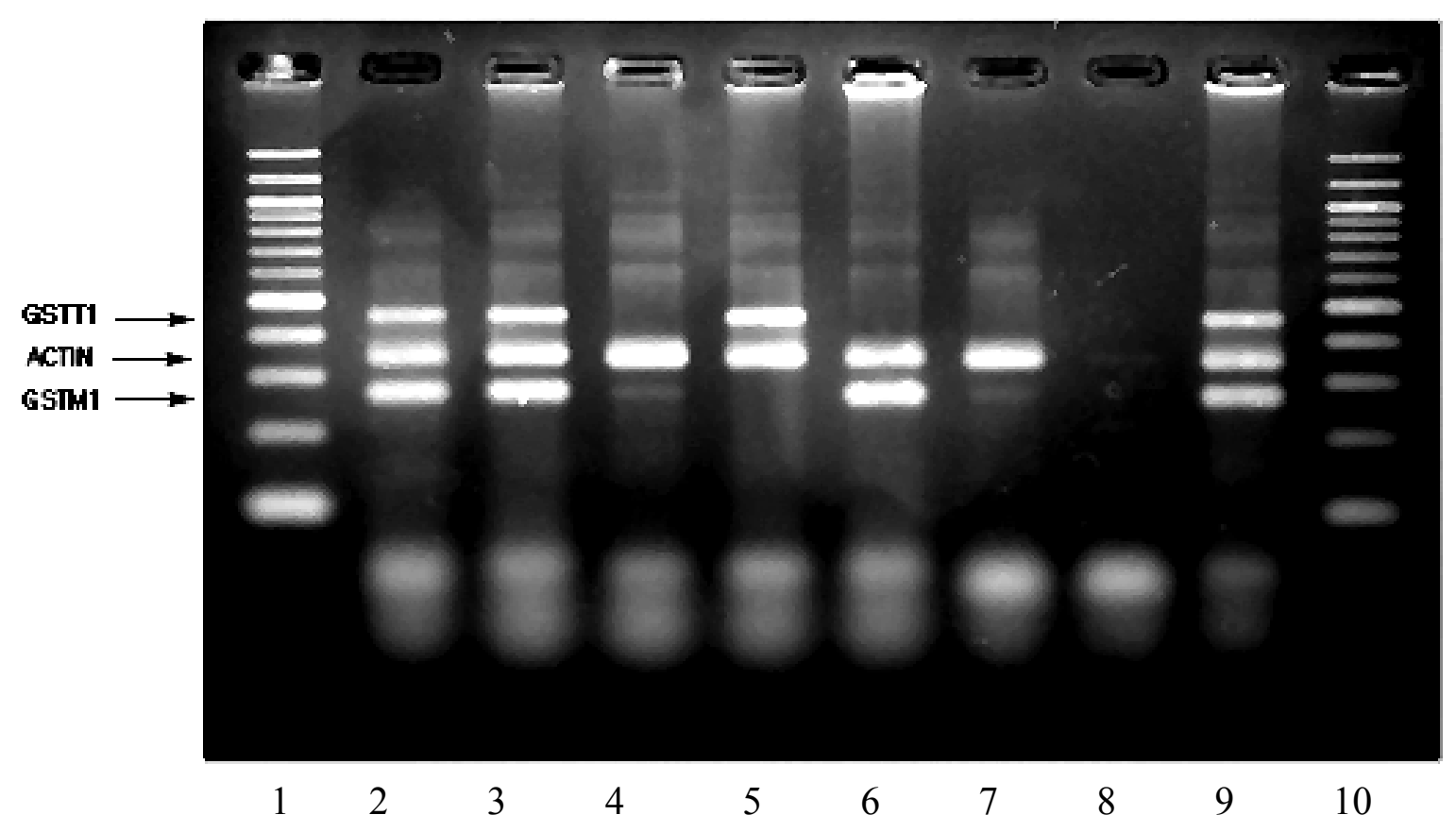

Figure 1: Agarose gel of the PCR products for detection of GSTM1 and GSTT1 deletion polymorphisms in seven specimens. GSTM1 - $273 \mathrm{bp}$, GSTT1- $480 \mathrm{bp}$, and *-actin - $320 \mathrm{bp}$. Lane 1, 10, molecular weight standards; lane $2,3,9$, GSTM $1 * 1 /$ GSTT $1 * 1$; lane 4, 7, GSTM $1 * 0 /$ GSTT $1 * 0$ ; lane 5, GSTM1*0/GSTT1*1; lane 6, GSTM1*1/ GSTT1*0; lane 8, negative control. 


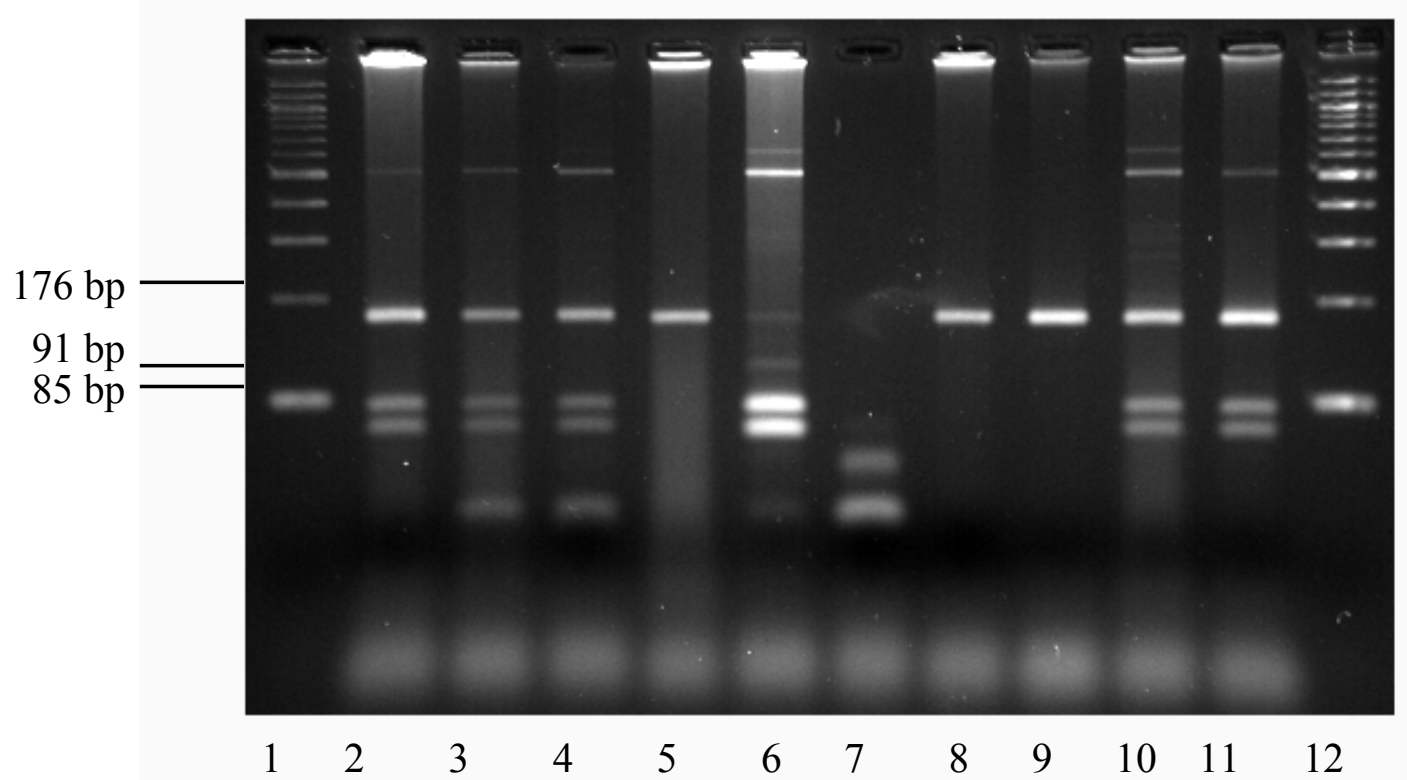

Figure 2: Agarose gel of the GSTP1 PCR products after digestion with Alw261 for detection of GSTP1 polymorphisms. The 176 bp GSTP1 PCR product is digested with Alw261, which does not cut the wildtype A sequence, but cleaves the $\mathrm{G}$ sequence to yield two restriction fragments of $91 \mathrm{bp}$ and $85 \mathrm{bp}$ length. Lane 1, 12, molecular weight standards; lane 2, 3, 4, 10, 11, heterozygous variant allele (GSTP1 Ile/Val); lane 5, 8, 9, homozygous wild type for GSTP1 (GSTP1 Ile/Ile); lane 6, homozygous variant allele (GSTP1 Val/Val); lane 7, negative control. 
presence of GSTM1 and GSTT1 fragments, either homozygous nondeleted or heterozygous (Figure 1). The GSTP1 polymorphism was detected by PCR followed by restriction enzyme digestion that distinguishes single base polymorphism by RFLP (Figure 2). We found that the GSTP1 polymorphism cannot be analyzed in the same multiplex PCR reaction as GSTM1 and GSTT1 because the GSTM1 fragment is also digested by Alu26I to a fragment of similar size as the GSTP1 fragment.

The results in Table 3 show a higher proportion of GSTM1 and GSTT1 homozygous deletions in the breast cancer group compared with the control group (55\% vs. 39\% for GSTM1 deletion and $18 \%$ vs. 13\% for GSTT1 deletion), but a slightly higher proportion of the GSTPl (i.e., Ile/Val or $\mathrm{Val} / \mathrm{Val}$ ) variant genotype in control group than in the case group (56\% vs. $52 \%)$.

The GST enzymes are involved in the detoxification of a variety of compounds and often have overlapping substrate specificity. We investigated whether certain profiles of GST genotypes may be associated with the risk of breast cancer. An effective detoxifier genotype with the presence of the GSTM1 and GSTT1 (GSTM1*1, GSTT1*1) gene and the homozygous wild type for GSTP1 (GSTP1 Ile/Ile) would be considered a low-risk genotype as Table 4 displays. A poor detoxifier genotype with GSTM1 and GSTT1 deletion $(G S T M 1 * 0, G S T T 1 * 0)$ and a heterozygous or homozygous variant allele (GSTP1 Ile/Val or GSTP1 Val/Val) would be considered high-risk. The proportion of cases with an effective detoxifier genotype was less than that of controls (16\% vs. $23 \%$, respectively). There were only two individuals from the case and two from the control group with $G S T M 1 * 0, G S T T 1 * 0$ and GSTP1Ile/Val. There were no individuals with $G S T M 1 * 0, \quad G S T T 1 * 0$ or $G S T M 1 * 0$ only and GSTP1Val/Val. Because GSTM1 and GSTP1 are responsible for conjugating PAH diolepoxides, which are considered the ultimate carcinogens of PAHs, the poor detoxifier genotype GSTM1*0, GSTP1Ile/Val

Table 4: Association between GST genotype profiles and breast cancer

\begin{tabular}{|c|c|c|c|c|c|}
\hline \multirow[t]{2}{*}{ Genotype } & \multirow[t]{2}{*}{ Allele } & \multicolumn{2}{|c|}{ Cases } & \multicolumn{2}{|c|}{ Controls } \\
\hline & & $\mathbf{n}$ & $(\%)$ & $\mathbf{n}$ & $(\%)$ \\
\hline effective detoxifier & $\begin{array}{l}\text { GSTM1*1, GSTT1*1, } \\
\text { GSTP1Ile/Ile }\end{array}$ & 10 & (16) & 9 & $(23)$ \\
\hline poor detoxifier & $\begin{array}{l}\text { GSTM1*0, } \\
\text { GSTP1Ile/Val }\end{array}$ & 16 & (26) & 8 & $(21)$ \\
\hline
\end{tabular}

The $\mathrm{p}$-value for the comparison of the effective detoxifier genotype in cases and controls is $\mathrm{p}=0.54$, for the poor detoxifier genotype $\mathrm{p}=0.38$. 
was considered. The proportion of cases with this genotype was more than that of controls ( $26 \%$ vs. $21 \%$, respectively). Even though the data are suggestive of a trend of increased risk with poor detoxification genotype, there were no statistically significant differences between cases and controls.

\section{DISCUSSION}

Genetic variants of carcinogen-metabolizing genes show distinct ethnic variation. The frequency of the GSTM1 deletion genotype ranges widely across different ethnic groups (from 30\% among blacks to 88\% among Samoans, Lin et al., 1994). The GSTT1 deletion polymorphism exhibits an even larger range in distribution between ethnic groups (Nelson et al., 1995). The ethnic variation of GSTP1 has not been studied in great detail. However, we have found that the GSTP1 homozygous variant genotype is very high in a Hispanic population from the El Paso area, occurring with the same frequency as the wild type genotype (Sanchez et al., unpublished data) whereas, it occurred in less than $10 \%$ in English individuals (Harries et al., 1997).

Many low-penetrance genetic variants have been studied for their potential role in breast cancer (Dunning et al., 1999). Several reports in the literature examining whether GSTM1 and GSTT1 null genotypes represent susceptibility factors for breast cancer, found either no association (Bailey et al., 1998) or a very weak association (Ambrosone et al., 1995, Gudmundsdottir et al., 2001). Interestingly, the GSTM1 and GSTT1 deletion genotype increases survival after treatment for breast cancer either by reducing the detoxification of chemotherapeutic drugs or by preventing therapy-generated reactive oxidant damage (Ambrosone et al., 2001). A statistically significant difference in genotype frequency of PAH-metabolizing genes of cases and controls has been reported previously for the GSTP1 Ile/Val polymorphism and for GSTM1 deletion in postmenopausal women (Helzlsouer et al., 1998). Susceptibility genes as exemplified by carcinogen-metabolizing genes are strongly dependent on exposure to carcinogens. Studies in Japanese populations that considered the interaction between GSTM1 and smoking found that lung cancer risk depended on the amount of cigarettes smoked (Nakachi et al., 1992). A recent study found a correlation of CYP1A1 genotype and breast cancer only among women with high PCB body burden (Moysich et al., 1999). Therefore, to assess the risk of a certain metabolic genotypes, one should take into consideration both the gene of interest and the exposure. Likewise, studies evaluating the risk of specific exposures should take into account interindividual genetic susceptibility. The studies mentioned above on GSTM1 and GSTT1 polymorphism and breast cancer found considered only exposure to tobacco smoke (Bailey et al., 1998, Ambrosone et al., 1995).

When considering low-penetrance traits like these GST polymorphisms one has to keep in mind that metabolic pathways like detoxification are very robust; systems are buffered because of the redundancy of enzymes. One GST gene can phenotypically compensate for genetic variation in another. Therefore, one should look at variants from multiple genes in a pathway. Only if several changes in the same pathway are present, is it likely that one will see an effect. We grouped subjects according to their genotype into an "effective metabolizer" group in which more effective detoxification is expected and a "poor metabolizer" group where, through deletion and single base substitution changes, 
less effective detoxification is expected. Additionally, one should know the extent of the exposure in question, since enzymes are rarely saturated for their substrates. Only individuals with high exposure (to polycyclic aromatic hydrocarbons, PAHs, through smoking or occupational exposure, for example) are presumed to be at increased risk.

The present study reports our initial efforts to determine if interindividual variations in metabolic capacity influences the risk of breast cancer and, more specifically, if polymorphisms in genes involved in PAH metabolism are related to cancer susceptibility. Even though many epidemiological studies support a role of GSTs in cancer development, and our data show a similar trend, the observed effect was not statistically significant. These inconsistencies might be due to the limited number of samples available and, therefore, a lack of statistical power. Furthermore, we were unable to control for potential confounding factors, such as race, age at menarche, age at menopause, and age at first full-term pregnancy. The main purpose of this study was to establish the techniques of polymorphism analysis in our laboratory.

\section{ACKNOWLEDGMENT}

We thank Randy Maddalena and Agnes Bodnar for the critical review of the manuscript.

\section{REFERENCES}

Ambrosone, C., Freudenheim, J., Graham, S., Marshall, J., Vena, J., Brasure, J., Laughlin, R., Nemoto, T., Michalek, A., Harrington, A., Ford, T., Shields, P. (1995) Cytochrome P4501A1 and glutathione $S$-transferase (M1) genetic polymorphism and postmenopausal breast cancer risk. Cancer Res. 55: 3483-3485.

Ambrosone, C., Shields, P. (1997) Molecular epidemiology of breast cancer. In: Etiology of Breast and Gynecological Cancers, pp 83-99.

Ambrosone, C., Sweeney, C., Coles, B., Thompson, P., McClure, G., Korourian, S., Fares, M., Stone, A., Kadlubar, F., Hutchins, L. (2001) Polymorphism in glutathione $S$-transferases (GSTM1 and GSTT1) and survival after treatment for breast cancer. Cancer Res. 61: 7130- 7135.

Awasthi,Y., Sharma, R., and Sinhal,S. (1994) Human glutathione S-transferases. Int. J. Biochem. 26: 295-308.

Bailey, L.R., Roodi, N., Verrier, C., Yee, C., Dupont, W., Parl F. (1998) Breast cancer and CYP1A1, GSTM1, and GSTT1 polymorphisms: evidence of a lack of association in Caucasians and African-Americans. Cancer Res. 58: 65-70.

Bell, D.A., Thompson, C.L., Taylor, J., Miller, C.R., Perera, F., Hsieh, L.L., and Lucier, G.W. (1992) Genetic monitoring of human polymorphic cancer susceptibility genes by polymerase chain reaction: application to glutathione transferase M. Environ. Health Persp. 98:113-117.

Bell, D.A., Taylor, J., Paulson, D., Robertson, C., Mohler, and Lucier, G. (1993) Genetic risk and carcinogen exposure: a common inherited defect of the carcinogen 
metabolism gene glutathione $S$-transferase M1 (GSTM1) that increases susceptibility to bladder cancer. J Natl. Cancer Inst. 85: 1159-1164.

Brockmoeller, J., Kerb, R., Drakoulis, N.Staffeldt, B and Roots,I. (1994) Glutathione Stransferase M1 and its variants $\mathrm{A}$ and $\mathrm{B}$ as host factors of bladder cancer susceptibility, a case-control study. Cancer Res. 54: 4103-4111.

Caporaso, N., and Goldstein, A. (1995) Cancer genes: single and susceptibility: exposing the difference. Pharmacogenetics 5: 59-63.

Charrier, J., Maugard, C.M., Le Mevel, B., Bignon, Y.J. (1999) Allelotype influence at glutathione $S$-transferase M1 locus on breast cancer susceptibility. Br. J. Cancer, 79: 346-53.

Dunning, A.M., Healey, C.S., Pharoah, P.D., Teare, M.D., Ponder, B.A., and Easton, D. (1999) A systematic review of genetic polymorphisms and breast cancer risk. Cancer Epidemiol., Biomarkers \& Prev., 8: 843-854.

Gudmundsdottir,,K., Tryggvadottir, L., Eyfjord, J.E. (2001) GSTM1, GSTT1 and GSTP1 genotypes in relation to breast cancer risk and frequency of mutations in the p53 gene. Cancer Epidem., Biomarkers \& Prev. 10: 1169-1173.

Harries, L.W., Stubbins, M.J., Forman, D., \& Wolf, C.R. 1997. Identification of genetic polymorphisms at the glutathione S-transferase pi locus and association with susceptibility to bladder, testicular and prostate cancer. Carcinogenesis 18: 641-644.

Hayashi, S., Watanabe, J., and Kawajiri, K. 1992. High susceptibility to lung cancer analysed in terms of combined genotypes of P4501A1 and mu-class glutathione Stransferase genes. Jpn. J. Cancer Res. 83: 866-870.

Hayes, J.D.\& Pulford, D.J. (1995) The glutathione S-transferase supergene family: Regulation of GST and the contribution of the isoenzymes to cancer, chemoprotection, and drug resistance. Crit. Rev. Biochem. Mol. Biol. 30: 445-600.

Helzlsouer, KJ., Selmin,O., Huang, H.-Y., Strickland, P.T., Hoffman, S., Alberg, A.J., Watson, M., Comstock, G.W.,, and Bell, D. (1998) Association between glutathione $S$-transferase $M 1, P 1$, and $T 1$ genetic polymorphisms and development of breast cancer. J. Natl. Cancer Inst 90: 512-518.

Hirvonen, A. (1999) Polymorphisms of xenobiotic-metabolizing enzymes and susceptibility to cancer. Env. Health Persp. 107: 37-47.

Kelsey, K.T., Spitz, M.R.Zuo, Z-F., Wiencke, J.K. (1997) Polymorphisms in the glutathione S-transferase class $\mathrm{mu}$ and theta genes interact and increase susceptibility to lung cancer in minority populations (Texas, United States). Cancer Cases \& Contr. 8: 554-559.

Ketterer, B., Harris, J.M., Talaska, G., Meyer, D.J., Pemble, S.E., Taylor, J.B., Lang, N.P., and Kadlubar, F.F. (1992) The human glutathione $S$-transferase supergene family, its polymorphism, and its effects on susceptibility to lung cancer. Environ. Health Persp. 98: 87-94.

Lin, H.J., Han, C-Y., Bernstein, D.A., Hsiao, W., Lin, B.K., Hardy, S. (1994) Ethnic 
distribution of the gluathione transferase Mu 1-1 (GSTM1) null genotype in 1473 individuals and application to bladder cancer susceptibility. Carcinogenesis 15: 1077-1081.

Liu, Y., Taylor, J., Linko, P., Lucier, W.and Thompson, C. (1991) Glutathione Stransferase $\mathrm{m}$ in human lymphocyte and liver: role in modulating formation of carcinogen-derived DNA adducts. Carcinogenesis 12: 2269-2275.

Madigan, M.P., Ziegler, R.G., Benichou, J., Byrne, C., Hoover, R. (1996) Proportion of breast cancer cases in the United States explained by well-established risk factors. $J$. Natl. Cancer Inst.87: 1681-1685.

Mannervik, B., Awasthi, Y., Board, P., Hayes,J., Di Ilio,C., Ketterer, B., Listowsky, I., Morgenstern, R., Muramatsu, M., Pearson, W., Pickett, C., Sato, K., Widersten, M., and Wolf, C. (1992) Nomenclature for human glutathione transferases. Biochem. J. 282: $305-308$.

McWilliams, J., Sanderson, B., Harris, E., Richert-Boe, K., and Henner, W. (1995) Glutathione S-transferase M1 (GSTM1) deficiency and lung cancer risk. Cancer Epidem., Biomarkers \& Prev. 4: 589-594.

Meyer, D., Coles, B., Pemble, S., Gilmore, K., Fraser, G., and Ketterer, B. (1991) Theta, a new class of glutathione transferases purified from rat and man. Biochem. J. 274: 409-414.

Moysich, K., Shields, P.G., Freudenheim, J.L., Schisterman, E.F., Vena, J.E., Kostyniak, P., Greizerstein, H., Marshall, J.R., Graham, S. Ambrosone, C.B. (1999) Polychlorinated biphenyls, cytochrome P4501A1 polymorphism, and postmenopausal breast cancer risk. Cancer Epidemiol., Biomark. Prev. 8: 41-44.

Nakachi, K., Imai, K., Hayashi, S.-I., and Kawajiri, K. (1992) Polymorphisms of the CYP1A1 and glutathione $S$-transferase genes associated with susceptibility to lung cancer in relation to cigarette doses in a Japanese population. Cancer Res. 53: 29942999.

Nakajima, T., Elovaara, E., Anttila, S., Hirvonen, A., Camus, A-M., Hayes, J.Ketterer, B., and Vainio, H. (1995) Expression and polymorphism of glutathione Stransferase in human lungs: risk factors in smoking-related lung cancer. Carcinogenesis 16: 707-711.

Nebert, D.W., McKinnon, R.A., and Puga, A. (1996) Human drug-metabolizing enzyme polymorphisms: effect on risk of toxicity and cancer. DNA and Cell Biol.15: 273280.

Nelson, H., Wiencke, J., Christiani, D., Cheng, T., Zuo, Z.-F., Schwartz, B., Lee, B-K., Spitz, M., Wang, M., Xu, X., and Kelsey, K. (1995) Ethnic differences in the prevalence of the homozygous deleted genotype of glutathione S-transferase theta. Carcinogenesis 16: 1243-1245.

Rebbeck,T. (1997) Molecular epidemiology of the human glutathione S-transferase genotypes GSTM1 and GSTT1 in cancer susceptibility. Cancer Epidemiol., Biomarkers \& Prev. 6: 733-743. 
Sambrook, J., Fritsch, E., and Maniatis, T. (1989) Molecular Cloning: A Laboratory Manual, Ed. 2, pp. 9.17-9.19. Cold Spring Harbor, NY.

Seidegard, J., Vorachek, W.R., Pero, R.W., and Pearson, W.R. (1988) Hereditary differences in the expression of the human glutathione transferase active on transstilbin oxide are due to a gene deletion. Proc. Natl. Acad. Sci. USA 85: 7293-7297.

Shields, P.G., Bowman, E.D., Harrington, A.M., Doan, V.T., and Weston, A. (1993) Polycyclic aromatic hydrocarbon-DNA adducts in human lung and cancer susceptibility genes. Cancer Res. 53: 3486-3492.

To-Figueras, J., Gene, M., Gomez-Catalan, J., Galan, M. C., Fuentes, M., Ramon, J. M., Rodamilans, M., Huguet, E., \& Corbella, J. (1997) Glutathione S-transferase M1 (GSTM1) and T1 (GSTT1) polymorphisms and lung cancer risk among Northwestern Mediterraneans. Carcinogenesis 18: 1529-1533.

Vaury, C., Laine, R., Noguiez, P., de Coppet, P., Jaulin, C., Praz, F., Pompon, D.,and Amor-Gueret, M. (1995) Human glutathione S-transferase M1 null genotype is associated with a high inducibility of cytochrome P4501A1 gene transcription. Cancer Res. 55: 5520-5523. 